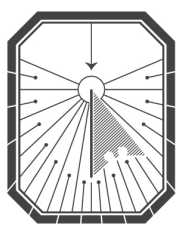

KYIV-MOHYLA

LAW \& POLITICS JOURNAL

KYIV-MOHYLA SCHOLARLY PEER-REVIEWED JOURNALS

Resilience in the Context of the Implementation of the EU-Ukraine Association Agreement

Author(s): Roman Petrov, Oksana Holovko-Havrysheva

Source: Kyiv-Mohyla Law and Politics Journal 7 (2021): 1-26

Published by: National University of Kyiv-Mohyla Academy

http://kmlpj.ukma.edu.ua/ 


\title{
Resilience in the Context of the Implementation of the EU-Ukraine Association Agreement
}

\author{
Roman Petrov \\ Professor \\ National University of Kyiv-Mohyla Academy, Ukraine \\ Oksana Holovko-Havrysheva \\ Associate Professor \\ National University of Kyiv-Mohyla Academy / \\ Ivan Franko National University of Lviv, Ukraine
}

\begin{abstract}
This article examines the extent of the practice of resilience in the process of the implementation of the EU-Ukraine Association Agreement (AA). Also, it analyses the main legislative and institutional tools promoting resilience of Ukraine's market integration with the EU. Two cases are considered in this study. The first case is the launch of negotiations on the EU-Ukraine Agreement on Conformity and Acceptance of Industrial Products (ACAA). The second case is an EU-Ukraine Trade Dispute on Export Woods Ban. In both cases the EU institutions and Ukraine display a high degree of flexibility to pursue a policy of resilience to achieve a high degree of EU Internal Market rapprochement. In the case of Ukraine, the institutional mechanism of the EU-Ukraine AA remains unused as a forum to discuss effectively and to find solutions for impeding problems in the bilateral cooperation agenda. Therefore, a coherent, transparent, and effective institutional cooperation framework in the bilateral EUUkraine relations is still needed.
\end{abstract}

Key Words: resilience, ACAA, pandemic, EU, Ukraine, EU Single Market, EU-Ukraine Association Agreement

\section{Introduction}

EU relations with the countries of the Eastern Partnership (EaP) are not homogeneous, thereby necessitating an individualized resilience approach and unique bilateral contractual relations of each EaP country with the EU. In the case of Georgia, Moldova, and Ukraine, the ambitious framework association agreements form the legal basis for

1 Eastern Partnership, accessed November 8, 2021 https://www.consilium.europa.eu/en/policies/ eastern-partnership. 
cooperation with the EU; whereas Armenia concluded a Comprehensive and Enhanced Partnership and Cooperation Agreement with the EU in 2017; Azerbaijan and the EU are currently negotiating the new partnership agreement, and their relations are based on the outdated Partnership and Cooperation Agreement of 1999; in the case of Belarus, the EU follows the policy of critical engagement since 2016, and, therefore, no framework contractual document is in place (Council Conclusions on Belarus, 2016). ${ }^{2}$ The EU plays a crucial role in modernizing economies and supporting policy reforms in the EaP region. This approach allows the EU to enhance its resilience toolbox by developing models to deal with the varying crises, and by ascertaining the cooperation and mutual assistance network for efficient cooperation in the EaP region. ${ }^{3}$

This article focuses on Ukraine being the country with the most advanced bilateral contractual framework with the EU, and as one of the most pro-European countries in the EaP region. The purpose of this article is to scrutinize if the existing contractual framework with the EU effectively contributed to the resilience approach in Ukraine. Section 1 deals with the notion of resilience in the context of the Ea P. Section 2 of the paper analyses the general framework of EU-Ukraine legal cooperation in the domain of the EU Internal Market and explains the historic background against which the EU-Ukraine Association Agreement entered into legal force and became a lynchpin of economic and legal reforms in Ukraine. It further focuses on the AA's implementation and approximation issues as key aspects of legal and policy resilience. Furthermore, Section 2 explores EU-Ukraine cooperation in the EU internal market field, and analyses various resilience tools applied by the EU and Ukraine. Subsequently, Section 3 scrutinizes the EU's resilience policy towards Ukraine through two case studies. The first case study looks at the launch of negotiations on the EU-Ukraine Agreement on Conformity and Acceptance of Industrial Products (ACAA) through the EU's resilience toolbox. The second case scrutinizes the EU-Ukraine trade dispute on a wood export ban and its relevance for the EU's resilience policy. The concluding part of the paper focuses on the challenges faced both by the EU and Ukraine in their recent bilateral relations. It is argued that effective institutional cooperation framework in the bilateral EU-Ukraine relations is still to be matured.

Council Conclusions on Belarus, Council of the EU, Press Release, February 15, 2016, accessed November 8, 2021, https://www.consilium.europa.eu/en/press/press-releases/2016/o2/15/facbelarus-conclusions.

Stefan Lorenzmeier, Roman Petrov and Christopher Vedder, eds., EU External Relations Law: Shared Competences and Shared Values in Agreements Between the EU and Its Eastern Neighbourhood (Heidelberg: Springer, 2021) 284; Peter van Elsuwege, and Roman Petrov, eds., Post-Soviet Constitutions and Challenges of Regional Integration: Adapting to European and Eurasian integration projects (London: Routledge Press, 2017) 232; Tobias Schumacher, Andreas Marchetti and Thomas Demmelhuber, eds., The Routledge Handbook on the European Neighbourhood Policy" (London: Routledge Press, 2017) 584; Peter van Elsuwege and Roman Petrov, eds., Legal Approximation of EU Law in the Eastern Neighbourhood of the EU: Towards a Common Regulatory Space? (London: Routledge Press, 2014), 268. 


\section{Conceptualizing Resilience in Context of the Eastern Partnership}

Climate change, the migration crisis, and the outbreak of COVID-19 have caused unpredictable difficulties for societies and economies worldwide pointing out the need for joint multinational efforts to mitigate the negative impacts of crises. The EU offers multidimensional solutions for its Member States, helping them to combat the negative consequences of the pandemic and other crises inside the EU. However, crises such as the Covid-19 pandemic reach far beyond the borders of the EU and have important repercussions for its relations with neighboring states. The EU and third countries alike face the necessity to apply a wide array of resilience instruments to maintain the previously achieved levels of market integration.

At the EU level, the resilience debate was initially linked to environmental issues and economic policies. The development of the EU's systematic approach towards resilience issues occurred in 2012 when the EU linked its humanitarian aid policies with its development policies, ${ }^{4}$ addressing the resilience phenomenon predominantly from economic and environmental perspectives. In 2013, drawing on prior work by the UN, the EU formulated its own approach to resilience and defined it as "the ability of an individual, community, country or a region to prepare, resist, adapt and quickly recover from stress and shocks, without undermining the long-term prospects of its development." 5 The EU's vision on resilience took more concrete shape during the period from 2012 to 2016 , and in 2014 the EU introduced resilience-check instruments for its development and humanitarian aid policies. ${ }^{6}$ In 2021 the EU instrumentalized these processes through the resilience dashboards, which serve as the basis for measuring the resilience of the EU, its Member States and non-EU countries and assessing their vulnerability and capacities in the real lifetime. ${ }^{7}$

Importantly for this paper's analysis, the Global Strategy for the European Union's Foreign and Security Policy (hereafter-EUGS 2016) extended the reach of the resilience discourse to the EU's external actions. The EUGS 2016 turned resilience into a key concept, which addresses the existential challenges the EU faces and provides a set of policy instruments and tools to anticipate and manage the adverse effects of

Commission, "Commission Staff Working Document: SHARE: Supporting Horn of Africa Resilience," SWD (2012) 102 Final, 2012.

Commission, "Communication from the Commission to the European Parliament and the Council-The EU Approach to Resilience: Learning from Food Security Crises," COM (2012) 586 Final, 2012:5.

6 Commission, “General Guidance-Resilience Marker," Ref. Ares (2014)3883617, 2014; Commission, “Resilience Marker Assessment Card," Ref. Ares (2014)3883617, 2014.

Commission, "Resilience Dashboards," accessed November 8, 2021, https://ec.europa.eu/info/ strategy/strategic-planning/strategic-foresight/202O-strategic-foresight-report/resilience-dashboards_en. 
crises. ${ }^{8}$ The EU's approach to resilience is based on the premise that the individual behavior of citizens shapes the implementation of the EUGS 2016 as much as the collective conduct of social groups and existing state policies. Furthermore, the EU depends upon democratic institutions and a rule-based international order. In this way, the EUGS 2016 introduces the debate about the impact of individuals on policy-making and individual responsibility for policy decisions into the resilience discourse. It also links the resilience debate to broader discussions about EU values in foreign policy and emphasizes communication as a key instrument in developing resilience-based policies. $^{9}$

Furthermore, resilience has also become a key policy concept in the EU's relations with its close and far neighborhood, especially those countries in the Eastern Partnership (EaP). In May 2020, the EU adopted the Joint Communication "Eastern Partnership Policy beyond 2020: Reinforcing Resilience - an Eastern Partnership that delivers for all," ${ }^{10}$ which seeks to enhance the cooperation in four EaP-related priority areas: stronger economy, stronger connectivity, stronger society, and stronger governance. This communication set out resilience as an overarching objective for the EU's long-term cooperation with the EaP countries. The focus is put on maintaining their economic resilience, more specifically, their sustainability and integration, environmental and climate resilience, resilience during digital transformations, social resilience for the establishment of inclusive and fair societies and, last but not least, a set of policy-related resilience features aimed to ensure "... accountable institutions, the rule of law and security." 11 Taken together, these long-term objectives of the EU's policies towards the neighborhood countries prioritize the following: 1) economic resilience aspects (sustainability, growth, digital economy, circular economy, and climate issues); 2) establish links to policy resilience aspects (accountability, transparency of governance processes and institutions involved); 3 ) legal resilience aspects (ensuring rule of law as the key value, combatting corruption, and implementing the conventional framework

8 Council Conclusions, "The Strategy Document—Shared Vision, Common Action: A Stronger Europe: A Global Strategy for the European Union's Foreign and Security Policy", Council of the EU, Press Release, November 14, 2016, accessed November 8, 2021, https://eeas.europa.eu/ archives/docs/top_stories/pdf/eugs_review_web.pdf. Joint Communication "A Strategic Approach to Resilience in the EU External Action," JOIN (2017) 21 final 2017.

10 Commission, High Representative of the Union for Foreign Affairs and Security Policy, "Communication to the European Parliament, the European Council, the Council, the Economic and Social Committee, the Committee of Regions: Eastern Partnership Policy Beyond 202O: Reinforcing Resilience - an Eastern Partnership that delivers for all," SWD(2O2O) 56 final 2020.

11 Commission, High Representative of the Union for Foreign Affairs and Security Policy, "Joint Staff working document: Recovery, Resilience and Reform: post 2020 Eastern Partnership priorities," SWD (2021), 186 final 2021: 18. 
for the EU's relations with the EaP countries); 4) political resilience (addressing the security aspects).

The EU defines resilience as one of the key points of the EUGS 2016. Therein, it states that the

"EU will promote a rules-based global order. The EU foster the resilience of its democracies ... our values will determine our external credibility and influence." ${ }^{12}$

Furthermore, the European Council defines resilience as encompassing the following characteristics:

"the adaptability of states, societies, communities and individuals to political, economic, environmental, demographic or societal pressures, in order to sustain progress towards national development goals; the capacity of a state - in the face of significant pressures to build, maintain or restore its core functions, and basic social and political cohesion, in a manner that ensures respect for democracy, rule of law, human and fundamental rights and fosters inclusive long-term security and progress; the capacity of societies, communities and individuals to manage opportunities and risks in a peaceful and stable manner, and to build, maintain or restore livelihoods in the face of major pressures."13

Alongside, and fostered by applications of 'resilience' by the EU institutions, an ever-growing literature on the conceptualization of the term has developed. However, scholars faced many doctrinal and practical challenges to offer a homogeneous understanding of the notion of 'resilience' in EU studies. For instance, Jonathan Joseph and Ana E. Juncos emphasize the ambiguous nature of resilience. They argue that resilience is

"a way of thinking, and [...] cannot be externally engineered" and remains "ambiguous" in many aspects, particularly "whether resilience is about risks or resources, whether resilience means stability or change, and what is the role of values." ${ }^{14}$

12 Council Conclusions, The Strategy Document, 2016: 8.

13 Joint Communication", JOIN (2017) 21 final 2017, accessed November 10, 2021, https://eur-lex. europa.eu/legal-content/EN/TXT/HTML/?uri=CELEX:52017JCoo21\&from=EN.

14 Jonathan Joseph and Ana E. "Resilience as an Emergent European Project? The EU's Place in the Resilience Turn," Journal of Common Market Studies, 57, no. 5 (May 2019): 998, https://doi. $\operatorname{org} / 10.1111 /$ jcms.12881. 
Nathalie Tocci has also stressed that resilience is a driving leitmotif and practice for many EU policies. She argues that that resilience serves as a building block of EU governance to foster some degree of homogeneity across EU policies, actors and institutions, especially by connecting European values and principles ("principled pragmatism") to the wider world and, in particular, the EU's neighborhood. ${ }^{15}$

Elena A. Koresteleva and Trine Flockhart advance two specific meanings of resilience:

"1) as a quality of an entity such as a system, organization, or even a person, and 2) as an analytic of governance in the EU." 16

Moreover, Tatiana Romanova highlights the dynamic nature of resilience in internal and external domains of the EU. At the same time, the author is critical about the implementation phase of resilience and argues that "the emphasis on resources and approach to values adopted in neighborhood and development policies brought this policy implementation closer to the theoretical writings on resilience." 17 Gilles Rouet and Gabriela Carmen Pascariu go further and link resilience to EU policies. The authors particularly emphasize the relevance of resilience for the EU EaP and confirm that resilience is a key tool to achieve the aim of strengthening the EaP's political association and economic integration, which must be based on shared interests and values (democracy, the rule of law, respect of human rights, and fundamental freedoms $) .18$

From an economic dimension, resilience is investigated at macro- and micro-levels, addressing the ability of the economy to recover from or adjust to external shocks, combined with the ability to use positive effects and opportunities. Also it is proposed that the resilience index should be measured on indicators such as the macroeconomic stability (fiscal deficit, unemployment and inflation, external debts), microeconomic market efficiency (Economic Freedom of the World Index measuring the performance of the financial markets, labor and business), good governance perspectives (legal structures and security of property risks focusing on the performance of the judicial system, court's impartiality, protection of intellectual property rights, involvement of military into ensuring the rule of law and legal order, the integrity legal system and

15 Nathalie Tocci, "Resilience and the Role of the European Union in the World," Contemporary Security Policy, 41, no. 2 (July 2020): 176-194, https://doi.org/10.1080/1352326o.2019.1640342.

Elena A. Korosteleva and Trine Flockhart, "Resilience in EU and International Institutions: Redefining Local Ownership in a New Global Governance Agenda," Contemporary Security Policy, 41, no. 2 (July 2020): 153-175, https://doi.org/10.1080/13523260.2020.1723973.

Tatiana Romanova, “The Concept of 'Resilience' in EU External Relations: A Critical Assessment," European Foreign Affairs Review 24, no. 3 (2019): 350, https://kluwerlawonline. com/journalarticle/European+Foreign+Affairs+Review/24·3/EERR2019029. Gilles Rouet and Gabriela Carmen Pascariu, eds, “Resilience and the EU's Eastern Neighbourhood Countries," (London: Palgrave, Springer, 2019): 548. 
political system performance), and social development (performance of health and education sectors).$^{19}$

\section{General Framework of the EU-Ukraine Cooperation}

\subsection{Legislative and Regulatory Approximation Dimension in Relations between the EU and Ukraine}

The EU-Ukraine AA replaced the outdated Partnership and Cooperation Agreement (PCA) as the basic legal framework of EU-Ukraine relations on June 27, 2014. ${ }^{20}$ Against the political background of the 2004-2005 'Orange Revolution,' Ukraine was the first European Neighborhood Policy (ENP) country to start negotiations on a new Association Agreement as part of a general revision of the bilateral legal framework in March 2007. Bilateral negotiations on the EU-Ukraine deep and comprehensive free trade area (DCFTA) were only launched in February 2008, after Ukraine's accession to the WTO. A political agreement was reached in December 2011 and the AA was initiated in March 2012. The DCFTA part was only initiated in July 2012. On May 15, 2013, the European Commission adopted proposals for a Council Decision on the signing and conclusion of the EU-Ukraine AA. ${ }^{21}$ Nevertheless, this agreement was not immediately signed due to EU demands for Ukraine to abandon practices of selective justice (particularly the unlawful imprisonment of opposition leader Yulia Tymoshenko from August 5, 2011 to February 2014) ${ }^{22}$ and to align the Ukrainian judiciary and law enforcement systems with European standards. ${ }^{23}$

Eventually, on the eve of the EaP Summit in Vilnius, the Ukrainian Government under prime-minister Mykola Azarov decided to suspend the process of preparation for signature of the AA in order

19 Lino Briguglio, Gordon Cordina, Nadia Farrugia, and Stephanie Vella, "Economic Vulnerability and Resilience Concepts and Measurements", UNU Wider, Research Paper No. 2008/55, (May 2008), https://www.econstor.eu/bitstream/10419/45146/1/571437761.pdf. Association Agreement between the European Union and its Member States, of the one part, and Ukraine, of the other part, (2014) OJ L 161, 2014.

21 Commission, "Signature of Association Agreement with the EU will depend on Ukraine's performance," Press Release, IP/13/436, May 15, 2013, accessed November 8, 2021, https:// ec.europa.eu/commission/presscorner/detail/en/IP_13_436. Mark Urban, "The Yulia Tymoshenko contradiction," BBC News, December 10, 2013, accessed November 8, 2021, https://www.bbc.com/news/world-europe-25305254.

23 Council of the European Union, "3209th Foreign Affairs Council Meeting: Council Conclusions on Ukraine," December 10, 2012, accessed November 8, 2021, https://www.consilium.europa.eu/ uedocs/cms_data/docs/pressdata/EN/foraff/134136.pdf. 
"to ensure the national security of Ukraine and to recover trade and economic relations with the Russian Federation." ${ }^{24}$

Arguably, the Ukrainian government's decision cannot be disconnected from the Russian proposal to establish a Eurasian Economic Union building upon the existing customs union between Russia, Belarus, and Kazakhstan. ${ }^{25}$ Following these news, hundreds of thousands of Ukrainians took to the streets. The ensuing Maidan revolution led to the dismissal of President Victor Yanukovych on February 22, 2014 and the establishment of an interim government under the leadership of Arseniy Yatsenyuk. Proceeding with the signature of the EU-Ukraine AA was a clear short-term objective for the new authorities in Kyiv. On June 27, 2014, the entire text of the EU-Ukraine AA was solemnly signed in Brussels along with the EU-Moldova and EU-Georgia AAs. A major impediment for timely entry into legal force of the EU-Ukraine AA was caused by the results of the advisory referendum in the Netherlands on April 6, 2016 (61\% of votes were against ratification of the agreement). The Dutch Senate approved the Act of Ratification on May 30, 2017 after the Dutch parliamentary elections. Soon afterwards, on September 1, 2017, the EU-Ukraine AA acquired full legal force and became part of the legal orders of the EU, its Member States, and Ukraine.

One of the core objectives of the EU-Ukraine AA is

"to establish conditions for enhanced economic and trade relations leading towards Ukraine's gradual integration in the EU Internal Market, including by setting up a Deep and Comprehensive Free Trade Area [...] and to support Ukrainian efforts to complete the transition into a functioning market economy by means inter alia, the progressive approximation of its legislation to that of the Union." 26

Therefore, legislative approximation is considered a key tool to ensure the gradual and resilient integration of Ukraine into the EU Single Market and the effective implementation of the EU-Ukraine AA. The implementation and application of the AA within the legal system of Ukraine is governed by its constitution. ${ }^{27}$ Overall, the

24 Decision of the Cabinet of Ministers of Ukraine of November 21, 2013, No. 905-p, accessed November 8, 2021, https://zakon.rada.gov.ua/laws/show/905-2013-\%D1\%8o\#Text.

25 Guillaume van der Loo and Peter van Elsuwege, "Competing Paths of Regional Economic Integration in the Post-Soviet Space: Legal and Political Dilemmas for Ukraine," Review of Central and East European Law, 37 (4) (2012): 421-447.

26 AA, 2014: Art. 1(d).

27 Constitution of Ukraine, Records of the Verkhovna Rada of Ukraine, No. 30, Art. 141, July 23, 1996, (1996): Art. 9. 
2019 constitutional amendments ${ }^{28}$ reflected the European aspirations of the Ukrainian population and political elites.

The Ukrainian legislature, executive, and judiciary consider the AA not merely an ordinary international agreement but a complex legal framework that contains specific norms that govern the functioning of the association relations between the EU and Ukraine, as well as measures to ensure the gradual integration into the EU internal market and the effective functioning of the EU-Ukraine DCFTA. However, Ukraine's integration into the EU internal market is not straightforward but strongly linked to the EU's policy of conditionality and the overall resilience of EU-Ukraine relations. The EU-Ukraine AA bears significant economic and legal importance for Ukraine and constitutes a comprehensive roadmap for reforms in Ukraine. ${ }^{29}$ Formally, further integration of Ukraine into the EU internal market depends on the effective application of the vast scope of the "pre-signature" and "post-signature" EU acquis ${ }^{30}$ within the legal system of Ukraine. The scope of the EU acquis to be applied by Ukraine covers primary and secondary EU laws, EU legal principles, common values, and even case law of the Court of Justice of the European Union (CJEU), as well as specific methods of interpretation of the relevant EU acquis within the Ukrainian legal system. Hitherto, the Ukrainian legal system had not faced a necessity to implement and effectively apply the dynamic legal heritage of an international supranational organization. The rare exception hereto can offer the Ukrainian practices of the application of the EU sectoral "energy" acquis under the framework of the Energy Community, which Ukraine joined in 2010. ${ }^{31}$ Subsequently, Ukraine's adherence to the dynamic EU acquis via the AA will encapsulate a plethora of challenges to its national legal order. However, formal "black letter" approximation of Ukrainian legislation to the EU acquis cannot lead to closer political, economic and legal integration into the EU without a positive and convincing Ukrainian record of sharing EU common values and complying with the EU's strict conditionality policy, as stipulated in the EU-Ukraine AA Preamble:

"ACKNOWLEDGING that the political association and economic integration of Ukraine with the European Union will depend on progress in the implementation of this Agreement as well as Ukraine's track record in ensuring respect for common values,

28 Constitution of Ukraine, 1996: Art. 85(5), Art. 102, Art. $116\left(1^{1}\right)$ as amended in 2019.

29 See "Association with EU is Roadmap for Ukraine's Reforms, which is Fulfilled only by $15 \%$ Poroshenko" (2017), Interfax-Ukraine, November 20, 2017, accessed November 8, 2021, https:// en.interfax.com.ua/news/general/463275.html. Roman Petrov, "Exporting the Acquis Communautaire through EUExternal Agreements," (Baden-Baden, Germany: NOMOS, 2011), 313.

31 Roman Petrov, "Energy Community as a Promoter of the European Union's "energy acquis" to its Neighbourhood", Legal Issues of Economic Integration, 38(3) (2012): 333. 
and progress in achieving convergence with the EU in political, economic and legal areas." ${ }^{32}$

Article 474 of the EU-Ukraine AA affirms that "Ukraine will carry out gradual approximation of its legislation to EU law" as referred to in no less than 44 annexes to the agreement and based on specific commitments and mechanisms identified in both the annexes and specific titles to the agreement. Separate approximation clauses can be found in Title IV of the DCFTA, Title V on Economic and Sector Cooperation, and Title VI on Financial Cooperation. The most elaborate approximation clauses can be found in Title IV on the establishment of the DCFTA. In several DCFTA Chapters, the process of legislative approximation is clearly linked to additional access to the EU Internal Market. For example, in technical barriers to trade, Ukraine must "incorporate the relevant EU acquis" 33 in line with the timetable set out in Annex III. Similarly, in Sanitary and Phytosanitary Measures (SPS), Ukraine "shall" approximate its sanitary, phytosanitary, and animal welfare legislation to that of the EU as set out in Annex V. ${ }^{34}$

The most detailed provisions on legislative approximation are included in DCFTA Chapter 6 on Services, Establishment and Electronic Commerce, more specifically in its sub-sections on Postal and Courier Services, Electronic Communications, Financial Services and International Maritime Transport Services. ${ }^{35}$ These all contain the same approximation clause according to which

"Ukraine shall ensure that its existing laws and future legislation will be gradually made compatible with the EU acquis." 36

These provisions are the only ones in the AA that explicitly oblige Ukraine to also approximate its "future" legislation to the EU acquis. Annex XVII ${ }^{37}$ contains "General principles and obligations" on legislative approximation. This determines how the listed EU legislation will be made binding upon the Parties and "made part of Ukraine's internal legal order." ${ }^{38}$ In reflecting - but not copying - Article 288 TFEU, Article 2 of this Annex specifies that an act in this Annex corresponding to an EU Regulation or Decision 'shall as such be made part of the internal legal order of Ukraine' whereas an act corresponding to an EU Directive "shall leave to the authorities of Ukraine the choice of form and method of implementation". This practice goes alongside the EU approach, that according to the Article 288 TFEU, a Regulation is "directly applicable" in all Member States whereas acts listed in the Annex corresponding to an EU Regulation

32 AA, 2014: Preamble.

33 AA, 2014: Ch. 3 Title IV.

34 AA, 2014: Art. 64(1).

35 These Sub-Sections, respectively Sub-section 4-7, are part of Section 5 "Regulatory Framework".

36 AA, 2014: Arts. 114, 124, 133 and 138.

37 AA, 2014: Appendix XVII-2 to XVII-5.

38 AA, 2014: Annex XVII, Art. 2 
(or Decision) "must be made part" of Ukraine's legal order, which means that the act still has to be transposed into Ukraine's legal system. This provision only appears in a limited number of integration agreements and was first used in the European Economic Area (EEA) Agreement.

One may argue that the EU-Ukraine AA is not merely a comprehensive legal document but also a template for ensuring better resilience of EU-Ukraine relations, for instance, by referring to institutional tools. Firstly, such institutional tool to support resilience of EU-Ukraine relations deal with the monitoring and supervision of the AA implementation, which includes the Association Council (AC), ${ }^{39}$ the Association Committee ${ }^{40}$ and the Parliamentary Association Committee. ${ }^{41}$ Furthermore, the EUUkraine summits were institutionalized as the highest cooperation body in the areas of political dialogue ${ }^{42}$ and a civil society platform was established to ensure an active role of civil society institutions during the AA implementation. ${ }^{43}$ The EU-Ukraine AA bodies are the least active in exercising their decision-making power among the EaP countries. ${ }^{44}$ They are primarily active at the level of the AC subcommittees (on sanitary and phytosanitary measures, on originating products and adjusting the customs schedules) and at the AC level, which addressed the amendment of the EU-Ukraine $\mathrm{AA}$, namely the annexes on public procurement and energy issues. The AC format started to be used actively for the regulation of the bilateral cooperation only in 2018 . Beforehand, from 2014 to 2018 , the AC predominantly dealt with topics concerning institutional and procedural issues (AC rules of procedure, the publication of the AC decisions and recommendations in Ukraine, the composition of the subcommittees and the arbitration panel on the dispute on the wood export ban).

Secondly, institutional tools to support resilience of the EU-Ukraine relations are linked to a unique intergovernmental dispute settlement mechanism (DSM) relating to legislative approximation. This procedure only applies to disputes concerning the interpretation and application of provisions relating to legislative approximation in a limited number of DCFTA Chapters (e.g. on Technical Barriers to Trade (Ch. 3), Sanitary and Phytosanitary Measures (Ch. 4), Customs and Trade Facilitation (Ch. 5), Establishment, Trade in Services and Electronic Commerce (Ch. 6), Public Procurement (Ch. 8) and Competition (Ch. 10)), "or which otherwise imposes upon a Party an obligation defined by reference to a provision of EU law." 45 If a dispute between the EU and Ukraine in relation to one of these chapters concerns a question of interpretation of

AA, 2014: Arts. 46o-463.

AA, 2014: Arts. 463-466.

AA, 2014: Arts. 467-468.

AA, 2014: Art. 46o (1).

AA, 2014: Arts. 469-470.

Guillaume van der Loo and Tinatin Akhvlediani, "Catch Me if You Can: Updating the Eastern

Partnership Association Agreements and DCFTAs," CEPS, May 18, 2020, accessed November 8, 2021, https:/www.ceps.eu/wp-content/uploads/2020/05/GVDL-and-TA-Updating-AA-DCFTAs.pdf.

AA, 2014: Art. 322. 
an EU legal provision, then the arbitration panel established to resolve the dispute will not decide the question "but request the Court of Justice of the European Union to give a ruling on the question," which is subsequently binding on the arbitration panel. ${ }^{46}$ This provision is unique in the sense that no other agreement that has been concluded by the EU grants the EU-Ukraine arbitration panel the competence to seek a preliminary ruling from the CJEU. Only in a limited number of other EU integration agreements can the CJEU respond to preliminary questions from a national court or tribunal: For instance, Art. 107 and Protocol 34 EEA Agreement. From this perspective, the provision appears to be one of the instruments ensuring a strong legal connection between the Ukrainian and EU legal systems with the aim of maintaining legal resilience during the AA's implementation.

Thirdly, an institutional tool to support resilience of the EU-Ukraine relations is constituted via ad hoc agencies that can either influence or interfere in the most urgent issues arising in EU-Ukraine relations and during the implementation of the EU-Ukraine AA. For instance, in 2014, the EU established the AA-based institutional framework "Support Group for Ukraine" 47 (SGUA) through a decision by the President of European Commission. The SGUA is a unique institutional mechanism embedded into the Directorate General for Neighbourhood and Enlargement Negotiations (DG NEAR), which aims to scrutinize the EU's cooperation with Ukraine and to coordinate assistance and financial support to Ukraine, a country in which external shocks in international politics and world economy can significantly influence the political trajectories of its development and may lead to a situation in which substantial reforms are delayed. The priority areas for the cooperation are predominantly linked with the implementation of the EU-Ukraine AA in the economic area and focus on agriculture and sanitary/ phytosanitary matters, reforming economic and fiscal policies, developing financial cooperation, and enhancing cooperation in energy and environmental sectors, as well as overall policy development, cooperation in the field of justice and home affairs, and sectoral cooperation in areas such as social matters, education, and research. The SGUA has a twofold task: On the one hand, it serves as the one-stop-window for EU initiatives on the enhancement of cooperation with Ukraine in different areas, which can be supported through its high-level expertise on Ukraine in sectoral matters. On the other hand, it also serves as the key contact point for Ukrainian authorities in the launching of cooperation with the EU, alongside the EU-Ukraine AA-based institutions. However, as Deanna Soloninka notes, the SGUA's impact on the relations between the EU and Ukraine remains rather limited since this body is not even well-known at EU-level.48

\footnotetext{
46 AA, 2014: Art. 322(2).

47 “Support Group to Ukraine," accessed November 8, 2021, https://ec.europa.eu/neighbourhood-enlargement/neighbourhood/countries/ukraine/sgua_en.

48 Deanna Soloninka, “The EU Support Group for Ukraine: Quiet Politics of Substantive Reform?” European Futures, July 22, 2020, accessed November 8, 2021, https://www.europeanfutures. ed.ac.uk/the-eu-support-group-for-ukraine-quiet-politics-of-substantive-reform.
} 
In other words, the AA offers legislative and institutional tools to support resilience in EU-Ukraine relations. In terms of legislative resilience, the objective of implementing the EU-Ukraine AA encourages the Ukrainian legal system to "export" the substantive scope of the EU-relevant acquis. For this purpose, the EU-Ukraine AA contains extensive approximation clauses that oblige Ukraine to approximate not only relevant existing but also future legislation to the EU acquis. Furthermore, the EUUkraine AA encompasses a unique possibility to refer matters of interpretation of any provisions of the AA that replicate the relevant EU acquis to the CJEU. Therefore, the legislative and regulatory approximation is a key instrument for ensuring resilience from legal and policy-making perspectives. Concerning institutional tools, the AAbased flexible institutional framework for the EU-Ukraine relations underpins their resilience. The Association Council, Association Committee, and Parliamentary Association Committee, the specific dispute settlement mechanism, and the Civic Society Platform can be seen as additional institutional instruments, aimed at ensuring the resilience of policy and governance reforms in a wider perspective. At the EU level, the ECJ and the European Commission are currently those institutions with the most significant influence on EU-Ukraine relations: the ECJ through the preliminary ruling procedure, and the Commission, through the SGUA — the Commission's task force unit dealing with EU-Ukraine Cooperation - which is embedded in DG NEAR since 2014. However, the role and importance of the SGUA in the development of EU-Ukraine relations seems to be underestimated and not visible.

\subsection{Single Market and Trade Dimension in Relations between the EU and Ukraine}

The Joint Communication "Eastern Partnership Policy beyond 2020: Reinforcing Resilience - an Eastern Partnership that delivers for all” emphasizes economic resilience as a top priority to be maintained throughout the cooperation with $\mathrm{EaP}$ countries with the objective of becoming a benefit for the involved partners through:

"Increased trade and further regional and bilateral integration of the economies of partner countries and the EU, together with cooperation for progressive decarbonization towards climate neutrality, embracing the opportunities from the twin ecological and digital transformation." 49

For the associated countries, economic resilience is linked to their phased integration into the EU Internal Market, conditional on the effective implementation of the EU acquis in such areas as public procurement, technical barriers to trade, market surveillance, sanitary and phytosanitary measures, customs services, and tax good governance standards. These form a substantial part of EU trade policy towards 
them. EU trade policy towards the EaP countries is based upon the rapprochement of the trade regimes between the EU and associated countries, giving them the possibility to become rule-shapers of the trade rules in an indirect way through the participation in the AA-based institutions.

Ensuring economic resilience in the case of Ukraine is linked to the fact that foreign trade is an essential component of Ukraine's economic development and growth. Like other EaP countries, Ukraine's international trade has been geographically determined, wherein deep economic and trade relations with the Russian Federation resulted in a longstanding orientation of Ukrainian trade policy and elites towards Russia.

The re-orientation of Ukrainian trade policy from the Russian market towards the EU took place after the so called "Dignity Revolution", which were followed by the annexation of Crimea by the Russian Federation in early 2014 and the outbreak of the war in Eastern Ukraine, whereby Ukraine lost 7.2\% of its territory. With the 2014 signature of the EU-Ukraine Association Agreement, and its entry into force in 2017, the new legal basis for trade relations between the EU and Ukraine, carrying the idea of creating a DCFTA, was established.

Consequently, the EU became the dominant destination of Ukrainian goods. However, Ukrainian trade flow for the period of 2013-2019 shows that the Ukrainian economy remains import-oriented with a considerably negative trade balance.

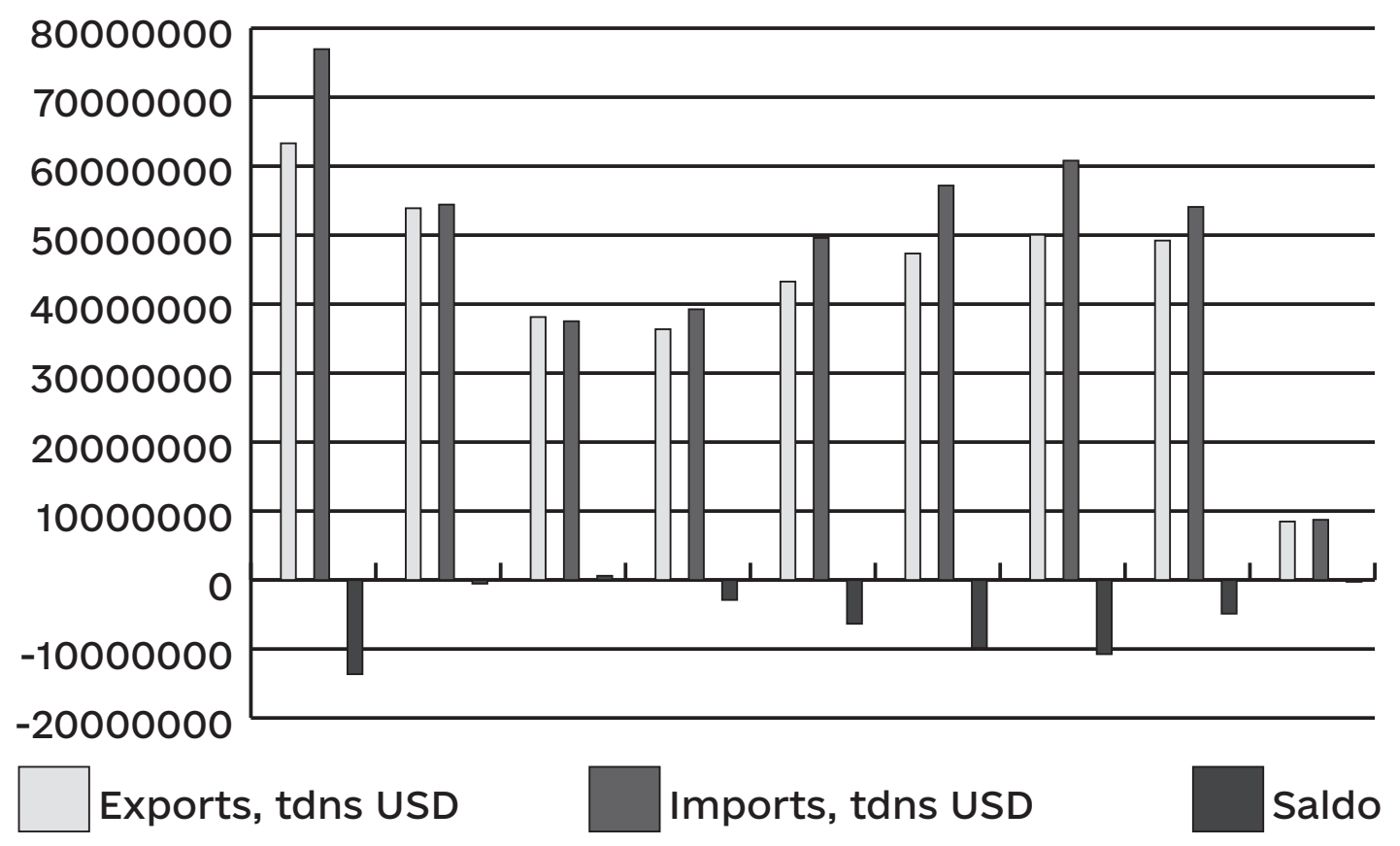

*For 2013, trade statistics include the annexed Crimea and Sevastopol,

For 2021, the available data covers the period of January-February 2021,

Source: Own calculations based on Ukrstat information, http://www.ukrstat.gov.ua ${ }^{50}$ 
The DCFTA provisions and rules on economic and sectoral cooperation create a framework for the application of EU rules on economic freedoms and access to the EU Single Market conditional upon the proper execution of the EU-Ukraine AA with a core requirement for Ukraine to align its legislation and regulatory practices to the EU acquis. The progress of approximation is also detrimental for the fostering of bilateral trade relations.

The Ukrainian economy is shaped by the fact that its foreign trade is import-oriented. The trade structures for imports and exports in January-February 2021 confirm the tendency that the agricultural sector remains in its leading position in Ukrainian exports with a $40 \%$ share in exports, whereas the structure of import is remarkably dominated by the inflow of machinery and equipment (19\%), as well as mineral products $(18 \%)$.

The 2020 pandemic outbreak caused many difficulties and losses in all economies worldwide. Trade relations have been re-shaped through the adopted state policies attempting to combat the virus' transmission and to ensure the access and availability of medical equipment and vaccines for their population.

Like most countries of the EaP, Ukraine's most prominent trade partners are the EU, the USA, and the Russian Federation. Meanwhile, China is also strengthening its trading position. The trade dynamics with these partners during the 2019-2021 period is marked by a traditionally high share of the EU in Ukrainian exports and imports, however, China already became the second largest trade partner for Ukraine in 2019, overriding the USA and the Russian Federation.

Cooperation between the EU and Ukraine in economic matters, as mentioned above, is connected to the legislative and regulatory approximation in the spheres of public procurement, technical barriers to trade, market surveillance, sanitary and phytosanitary measures, customs services, and tax good governance standards, wherein the degree of the approximation is differentiated. Thus, the Ukrainian government reports an $85 \%$ fulfillment of its obligations under the AA in the areas of public procurement and technical barriers to trade including the market surveillance, $62 \%$ in the matters of sanitary and phytosanitary measures, and $46 \%$ on customs issues and in financial matters. ${ }^{51}$ The most visible progress has been observed in the areas of public procurement and technical barriers to trade, which elevates the discussion of the ACAA and mutual recognition agreement between the EU and Ukraine to the top of the association agenda.

Regarding cooperation in public procurement matters, the EU-Ukraine Association Agreement aims at a gradual opening of access to public procurement markets in the EU and Ukraine respectively, which follows the Indicative Timetable for Institutional Reform, Legislative Approximation and Market Access (Annex XXI) with five indicative periods throughout which EU rules on public procurement are to be implemented in the domestic legal order of Ukraine. In 2014, Ukraine adopted the new law "On Public Procurement," which implemented a vast part of the EU acquis 
into national legislation, with the result that EU companies gained vast access to the Ukrainian public procurement market and vice versa, based on the Ukraine's joining of the WTO Public Procurement Agreement in 2016. Despite such achievements, EUUkraine cooperation in public procurement matters is difficult, due to a contradiction between the rules of membership in the WTO Public Procurement Agreement, which stipulates that mutual access to procurement markets does not require any additional changes in procurement rules on either side, while EU-Ukraine AA provisions make Ukraine's access to the EU public procurement market conditional upon the full implementation of the AA and approximation to the EU acquis.

Cooperation between the EU and Ukraine on technical barriers to trade is also rapidly developing. In the 2016-2021 period, Ukraine adopted a series of legislative acts and new regulatory frameworks. For instance, Ukraine adopted the legislation on the safety of non-food products, a state system of market surveillance and control of non-food products in 2016, thereby modernizing its legislation on liability and compensation of damages for defect products and technical standards for different industries and sectors (including medical equipment for in vitro, protective equipment aimed to be used in explosive environment, radio and telecom equipment. etc.). In 2O2O, Ukraine adopted EU standards as national standardization rules and canceled the application of the EN-conflicting rules; it also became a member to CEN, CENELEX and ETSI, and established a cooperation between the international and European accreditation agencies. A delay was encountered in the case of the legislation on packaging and packaging waste. Since 2016, Ukraine has been actively changing its regulatory and legislative framework on technical barriers to trade, so that so-called "industrial visa-free regimes" become the foremost priority. It needs to be mentioned that these achievements are not perceived very optimistically by the EU, since the time delays in implementation schedules in these areas are significant. Moreover, despite the fact that legislation has been adopted in Ukraine, an effective enforcement system is still lacking, thus diminishing the positive results of the legislative approximation, and highlighting the need to develop effective implementation instruments at executive and judiciary branch levels.

Among the priorities for the alignment of the trade regimes between the EU and associated countries, the legislative and regulatory approximation is crucial, since it opens the possibility for a mutual continuous and gradual opening of markets and the conclusion of special agreements - mutual recognitions agreements (MRA) and agreements on conformity assessment and acceptance of industrial products (ACAA), which address the technical administrative procedures necessary for a mutual opening of markets once parties agree thereto. Ukraine became the first of the EaP countries to lobby for the opening of negotiations on a conclusion of the ACAA with the EU. Despite initial reluctance on behalf of the EU, the perspective of the negotiations became visible. ${ }^{52}$

$5^{2}$ "Access of Ukrainian Goods to the EU Market. ACAA Agreement," April 15, 2021, accessed November 8, 2021, https://ukraine-eu.mfa.gov.ua/en/2633-relations/torgovelno-ekonomichne- 
Since the 2020 pandemic outbreak, the EU has offered a wide range of political and economic instruments to support economic and healthcare reforms in Ukraine. Since 2019, the EU has launched a support program to assist the healthcare sector needs, to support the small and medium enterprises (26 Mio Euro in 2019, 25 Mio Euro in 2020 as a part of the bilateral assistance package to Ukraine), and to grant a quick social relief package for the most affected areas and vulnerable groups in Ukraine under the Team Europe Initiative. The whole package of EU macro-financial assistance to Ukraine, as well as support programs of other international donors (the IMF, European Bank of Reconstruction and Development, etc.) is based on the principle of conditionality, meaning the continuity of democratic and structural reforms in Ukraine. ${ }^{53}$

In conclusion, the single market dimension of the cooperation of the EU with third countries, including Ukraine, is anchored in a policy of strong conditionality that implies the recognition by third countries of EU common values of human rights, democracy, rule of law, and fundamental freedoms as a wider framework of the cooperation in economic matters and mutual resilience of bilateral EU-Ukraine relations. The European Commission plays a crucial role in ensuring the application of the conditionality policy towards Ukraine and in monitoring the effective application of the EU-Ukraine AA.

\section{Internal Market Resilience in EU-Ukraine Cooperation}

EU-Ukraine relations have been marked by many external and domestic challenges that considerably impeded the effective implementation of the EU-Ukraine AA and the gradual integration of Ukraine into the EU Internal Market. Among them are challenges of either security (annexation of Crimea by Russia and Russian aggression in the Eastern Ukraine) or of economic nature (closure of Russian markets for Ukrainian products, economic crisis caused by COVID-19). In addressing all these issues, the European Commission has played a key role. In the following section two core challenges in EUUkraine relations are considered, against which the resilience theory can be tested. The first case is the launch of negotiations on the EU-Ukraine Agreement on Conformity and Acceptance of Industrial Products (ACAA). The second case is an EU-Ukraine Trade Dispute on Export Woods Ban.

spivrobitnictvo-ukrayina-yes/dostup-ukrayinskih-tovariv-do-rinku-yes-ugoda-asaa; "ACAA— Now at the Top of the Ukraine-EU Agenda," March 17, 2021, accessed November 8, 2021, https:// eceap.eu/publication/acaa-now-at-the-top-of-the-ukraine-eu-agenda. 


\subsection{Resilience during the negotiation of the EU-Ukraine ACAA}

The ACAA is a contractual mechanism (also known as mutual recognition agreements (MRAs)), aimed at the elimination of technical barriers in trade between the EU and third countries. Hitherto, the EU concluded ACAAs with very few third countries with developed market economies and advanced levels of mutual trade, such as Australia, Canada, Israel, Japan, New Zealand, Switzerland, USA. ${ }^{54}$ A potential EU-Ukraine ACAA may lead to deeper trade integration and better access of Ukrainian goods to the EU internal market. In practice, this would mean that Ukrainian exporters will be entitled to mark their goods with a "CE" label, enabling them to freely sell these products in the EU. Furthermore, the same would apply to exporters from EU Member States. The wording of the relevant provision of the EU-Ukraine AA perfectly mirrors the EU's policy of conditionality and explicitly links the possibility of concluding the ACAA to the fact that

"relevant Ukrainian sectoral and horizontal legislation, institutions and standards have been fully aligned with those of the EU. The ACAA will provide that trade between the Parties in goods in the sectors that it covers shall take place under the same conditions as those applying to trade in such goods between the Member States of the European Union." ${ }^{55}$

Consequently, the negotiation and conclusion of the ACAA was considered one of the 'carrots' which the EU could offer the Ukraine in case of a successful implementation and application of the EU-Ukraine AA. Ukraine has been striving for the ACAA since the entry into force of the EU-Ukraine AA in 2017. For this purpose, Ukraine has gradually departed from the Soviet-style standards (GOST) that eventually closed the doors for Ukrainian products into the countries of the Eurasian Economic Union. The European Commission invested considerable human, technical, and financial efforts in aligning Ukrainian conformity assessment and market surveillance bodies with those of the EU. However, the progress of the approximation efforts in area of EU Internal Market legislation has not been considered predominantly positive, as the EU Annual Reports on the implementation of the EU-Ukraine AA show. Following consistent pressure of the Ukrainian government, the EU eventually showed its readiness to start the ACAA negotiations with Ukraine at the end of 2019. In response to the October 2020

54 More information on EU Mutual Recognition Agreements is available at https://www.ema. europa.eu/en/human-regulatory/research-development/compliance/good-manufacturing-practice/mutual-recognition-agreements-mra. 
of the Implementation of the EU-Ukraine Association Agreement

to March 2021 EU assessment mission's results, the EU confirmed that the ACAA can be provisionally signed. ${ }^{56}$

Several factors explain the EU's initial reluctance to negotiate the ACAA with Ukraine. First, it was evidently caused by delays in the Ukrainian approximation efforts in the fields of technical and phytosanitary standards. The mutual recognition regime requires a high degree of conformity and mutual trust between the parties. Since the human and financial cost of the legislative approximation in these areas is high, Ukraine failed to perform well in these fields. Second, the European Commission was keen to complete the Brexit negotiation process and the negotiations on a Framework Agreement with Switzerland before launching its negotiations on the ACAA with Ukraine. ${ }^{57}$ Following active engagement of the Commission and consistent lobbying of the Ukrainian government, the negotiation process on the ACAA was launched in 2021.

\subsection{EU-Ukraine Dispute Settlement on Wood Export Ban}

Soon after the signing in 2014 and during the provisional application of the EU-Ukraine AA, the Ukrainian government introduced a 10-year export ban for all unprocessed wood originating in Ukraine. The EU considered this ban against the objective and spirit of the EU-Ukraine AA and consistently objected to this measure. After the formal governmental consultations of February 2019 failed to solve the issue, the EU requested the establishment of an arbitration panel on June 20, 2020. Notably, it was the first case of the EU requesting and establishing an arbitration panel under the framework of an agreement with a third country. The Arbitration Panel that was comprised of leading legal experts in WTO and EU law from the EU and Ukraine acted expediently and issued the final ruling on December 11, 2020.58 Therein, the Arbitration Panel concluded that any export bans are not compatible with Article 35 of the EU-Ukraine AA (illegality of export prohibitions by the Parties). Further, the export ban of unprocessed wood in place since 2015 was deemed not compatible with the relevant provisions of the GATT Agreement and the EU-Ukraine AA. Nevertheless, the Arbitration Panel considered that the export ban measures related to ten specific 'rare and valuable' wood species, which were partially justified through a health protection exception. ${ }^{59} \mathrm{In}$ line with this

56 Raul Mälk, "ACAA-now at the top of the Ukraine-EU Agenda", Estonian Center of Eastern Partnership, accessed November 8, 2021, https://eceap.eu/wp-content/uploads/2021/o3/ACAA$\%$ E2\%80\%93-now-at-the-top-of-the-Ukraine\%E2\%80\%93EU-Agenda.pdf. Informal interview with an EU Commission official in 2021.

$5^{8}$ Final Report of the Arbitration Panel established pursuant to Article 307 of the Association Agreement between Ukraine, of the one part, and the European Union and its Member States, of the other part "Restrictions applied by Ukraine on exports of certain wood products to the European Union," Lugano, Switzerland, December 10, 2020, accessed November 8, 2021, https:// trade.ec.europa.eu/doclib/docs/2020/december/tradoc_159181.pdf. 
ruling, the Ukrainian government was urged to take all necessary measures to ensure the implementation of the Arbitration Panel's ruling.

The wood export ban case constitutes another illustration of resilience in EUUkraine relations. On the one hand, the EU could not ignore the Ukrainian trading practice that contradicts the basic principles of the WTO and EU trade policies. Despite considering Ukraine a key participant of the EaP, concluding the most ambitious AA with it, and setting up the DCFTA, the EU had to articulate its strong standing on an issue of unfair trade behavior by Ukraine. Further, the EU had to consider that trade practices by the Ukrainian government may be taken up by other partners of the EU in the region and worldwide if not handled swiftly. On the other hand, the Ukrainian government had to balance between a delicate domestic political agenda (as lifting the wood export ban would lead to an excessive consumption of wood by EU producers and to an eventual depletion of Ukrainian wood resources). Finally, the Ukrainian government agreed with the ruling of the Arbitration Panel and confirmed its readiness to implement the required measures. A relevant draft law has been prepared by the Ukrainian government and submitted for the consideration of the Parliament of Ukraine. ${ }^{60}$

The European Commission played an essential role in ensuring a resilient EU economic policy cooperation with Ukraine in this case. Several factors warrant our consideration. First, the EU Commission exercised an annual monitoring of the application and implementation of the EU-Ukraine AA by Ukraine. This implies that the Commission regularly screens relevant Ukrainian legislation and trade practices. Furthermore, the Commission played a key role in providing technical and export support for the EU institutions and the Arbitration Panel. Second, the Commission took a bold decision in skipping the mediation procedure envisaged in the EU-Ukraine AA and went ahead with the initiation of the DSM. This constituted the first practical case of EU external relations law initiating a DSM under an EU bilateral agreements with third countries. It is possible that the European Commission was confident in the positive outcome of the dispute settlement with Ukraine for the EU, and, therefore, endeavored on a test of the DSM under the EU external agreement. ${ }^{61}$

6o Draft Law of Ukraine "On Amending the Law of Ukraine "On Peculiarities of the State Regulation of the Conduct of Entrepreneurial Activities Related to the Sale and Export of Wooden Materials," accessed November 8, 2021, https://www.me.gov.ua/Documents/ Detail?lang=uk-UA\&title=ProektZakonuUkrainiproVnesenniaZminDoZakonuUkrainiproOsob livostiDerzhavnogoReguliuvanniaDiialnostiSubktivPidprimnitskoiDiialnosti-PoviazanoiZReali zatsiiuTaEksportomLisomaterialiv\&fbclid=IwAR2A1cIIECQh4e3_Ld33Th9-bPTmXfx-m5VWHT_ miqMWdTj4cfz_jtJScOwo.

61 Informal interview with EU Commission official. 


\section{Conclusion}

This article scrutinizes the phenomenon of resilience in the course of the implementation of the EU-Ukraine AA. In particular, this paper analyzed if advanced legal and institutional level of the EU-Ukraine AA contributes to solving global and domestic challenges for the EU-Ukraine relations. The following observations are relevant in this regard.

First, the current framework of EU-Ukraine legal and economic cooperation (EaP and the EU-Ukraine AA) became a solid foundation for economic and legal reforms in Ukraine. Second, EU-Ukraine trade evolved rapidly in order contain some degree of resilience for Ukraine to be able to deal with various challenges and crises.

Two cases were analyzed to examine the extent of resilience in the economic relations between the EU and Ukraine, focusing on single market integration. The first case is the launch of negotiations on the EU-Ukraine Agreement on Conformity and Acceptance of Industrial Products (ACAA). The second case is an EU-Ukraine Trade Dispute on Export Woods Ban. These cases display a high degree of flexibility of both parties to pursue a policy of resilience to achieve a high degree of mutual trade and EU Internal Market rapprochement. The key role behind these efforts is played by the European Commission as the main promoter of the EU acquis and trade and economic policies in third countries. Nevertheless, these efforts also need to resonate with the priorities of the relevant institutional mechanism under the framework of the AA concluded by the EU with a third country. In the case of Ukraine, the institutional mechanism of the EU-Ukraine AA still remains unused as a forum to discuss effectively and to find solutions for impeding problems in the bilateral cooperation agenda. Furthermore, the Commission and its task force ad hoc institutions, like the SGUA, have produced a rather limited impact on economic and political reforms in Ukraine. Therefore, a coherent, transparent, and effective institutional cooperation framework in the bilateral EU-Ukraine relations is needed to enhance the effectiveness of the EUUkraine bilateral cooperation.

\section{Bibliography}

"ACAA - Now at the Top of the Ukraine-EU Agenda." March 17, 2021. Accessed November 8, 2021. https://eceap.eu/publication/acaa-now-at-the-top-of-theukraine-eu-agenda.

"Access of Ukrainian Goods to the EU Market. ACAA Agreement." April 15, 2021. Accessed November 8, 2021. https://ukraine-eu.mfa.gov.ua/en/2633-relations/ torgovelno-ekonomichne-spivrobitnictvo-ukrayina-yes/dostup-ukrayinskihtovariv-do-rinku-yes-ugoda-asaa.

“Association with EU is Roadmap for Ukraine's Reforms, Fulfilled by Only $15 \%$ Poroshenko" (2017). Interfax-Ukraine. November 20, 2017. Accessed November 8, 2021. https://en.interfax.com.ua/news/general/463275.html. 
EU Mutual Recognition Agreements. Accessed November 8, 2021. https://www.ema. europa.eu/en/human-regulatory/research-development/compliance/goodmanufacturing-practice/mutual-recognition-agreements-mra.

"Support Group to Ukraine." Accessed November 8, 2021. https://ec.europa.eu/ neighbourhood-enlargement/neighbourhood/countries/ukraine/sgua_en.

Association Agreement between the European Union and its Member States, of the one part, and Ukraine, of the other part. (2014) OJ L 161, 2014.

Briguglio, Lino, Gordon Cordina, Nadia Farrugia and Stephanie Vella. "Economic Vulnerability and Resilience Concepts and Measurements." UNU Wider. Research Paper No. 2008/55 (May 2008). Accessed November 8, 2021. https://www.econstor. eu/bitstream/10419/45146/1/571437761.pdf.

Commission, "Commission Staff Working Document: SHARE: Supporting Horn of Africa Resilience." SWD (2012) 102 Final. 2012.

Commission, "Communication from the Commission to the European Parliament and the Council— The EU Approach to Resilience: Learning from Food Security Crises." COM (2012) 586 Final. 2012.

Commission, "General Guidance-Resilience Marker." Ref. Ares (2014)3883617. 2014.

Commission, "Resilience Dashboards." Accessed November 8, 2021. https://ec.europa. $\mathrm{eu} /$ info/strategy/strategic-planning/strategic-foresight/2020-strategic-foresightreport/resilience-dashboards_en.

Commission, "Resilience Marker Assessment Card." Ref. Ares (2014)3883617 2014.

Commission, "Signature of Association Agreement with the EU will Depend on Ukraine's Performance." Press Release, IP/13/436, May 15, 2013. Accessed November 8, 2021. https://ec.europa.eu/commission/presscorner/detail/en/IP_13_436.

Commission, High Representative of the Union for Foreign Affairs and Security Policy. "Communication to the European Parliament, the European Council, the Council, the Economic and Social Committee, the Committee of Regions: Eastern Partnership Policy Beyond 202O: Reinforcing Resilience — an Eastern Partnership that delivers for all." SWD (2020) 56 final 2020.

Commission, High Representative of the Union for Foreign Affairs and Security Policy. "Joint Communication to the European Parliament and the Council: A Strategic Approach of Resilience in the EU's External Action." JOIN (2017), 21 Final 2017.

Council Conclusions on Belarus. Council of the EU. Press Release. February 15, 2016. Council Conclusions. "The Strategy Document-Shared Vision, Common Action: A Stronger Europe: A Global Strategy for the European Union's Foreign and Security Policy." Council of the EU. Press Release. November 14, 2016.

Council of the European Union. "3209th Foreign Affairs Council Meeting: Council Conclusions on Ukraine.” December 10, 2012 Accessed November 8, 2021. https:// www.consilium.europa.eu/uedocs/cms_data/docs/pressdata/EN/foraff/134136. pdf.

Decision of the Cabinet of Ministers of Ukraine of November 21, 2013 No. 905-p. Accessed November 8, 2021. https://zakon.rada.gov.ua/laws/show/905-2013-\%D1\%8o\#Text. 
Final Report of the Arbitration Panel Established Pursuant to Article 307 of the Association Agreement between Ukraine, of the one part, and the European Union and its Member States, of the other part "Restrictions Applied by Ukraine on Exports of Certain Wood Products to the European Union." Lugano, Switzerland. December 10, 2020. Accessed November 8, 2021. https://rade.ec.europa.eu/doclib/ docs/2020/december/tradoc_159181.pdf.

Joseph, Jonathan and Ana E. "Resilience as an Emergent European Project? The EU's Place in the Resilience Turn." Journal of Common Market Studies 57(5), (May 2019): 995-1011.

Konstytutsiia Ukrayiny [Constitution of Ukraine], Vidomosti Verkhovnoyi Rady Ukrayiny [Records of the Verkhovna Rada of Ukraine] No. 30, Art. 141, July 23, 1996.

Korosteleva, Elena A. and Trine Flockhart. "Resilience in EU and International Institutions: Redefining Local Ownership in a New Global Governance Agenda." Contemporary Security Policy 41, no. 2 (July 2020): 153-175. https://doi.org/10.108 o/13523260.2020.1723973.

Lorenzmeier, Stefan, Roman Petrov and Christopher Vedder, eds. EU External Relations Law: Shared Competences and Shared Values in Agreements Between the EU and Its Eastern Neighbourhood. (Heidelberg, Germany: Springer, 2021).

Mälk, Raul. "ACAA-now at the Top of the Ukraine-EU Agenda," Estonian Center of Eastern Partnership. Accessed November 8, 2021. https://eceap.eu/wpcontent/uploads/2021/o3/ACAA-\%E2\%80\%93-now-at-the-top-of-the-Ukraine $\%$ E2\%8०\%93EU-Agenda.pdf.

OECD. "Epidemiological Update:The COVID-19 Crisis in Ukraine." July 26, 2021. Accessed November 8, 2021. https://www.oecd.org/eurasia/competitiveness-programme/ easern-partners/COVID-19-CRISIS-IN-UKRAINE.pdf.

Petrov, Roman. "Energy Community as a Promoter of the European Union's "Energy Acquis" to its Neighbourhood." Legal Issues of Economic Integration, 38(3) (2012): $331-355$.

Petrov, Roman. "Exporting the Acquis Communautaire Through EUExternalAgreements." (Baden-Baden, Germany: NOMOS, 2011).

Proekt Zakonu Ukrayiny "Pro Vnesenniya Zmin do Zakonu Ukrayiny "Pro Osoblyvosti Derghavnogo Reguliuvannia Diyalnosti Subjektiv Pidpryyemnytskoyi Diyalnosti, Povyazanoyi z Realizaziyeyu ta Eksportom Lisomaterialiv" [Draft Law of Ukraine "On Amending the Law of Ukraine "On Peculiarities of the State Regulation of the Conduct of Entrepreneurial Activities Related to the Sale and Export of Wooden Materials"]. Accessed November 8, 2021. https://www.me.gov.ua/Documents/ Detail?lang=uk-UA\&title=ProektZakonuUkrainiproVnesenniaZminDoZakonuU krainiproOsoblivostiDerzhavnogoReguliuvanniaDiialnostiSubktivPidprimnitsk oiDiialnosti-PoviazanoiZRealizatsiiuTaEksportomLisomaterialiv\&fbclid=IwAR2 A1cIIECQh4e3Ld3STh9-bPTmXfx-m5VWHT_miqMWdTj4cfz_jtJScOwo.

Puls Ugody [Pulse of the Agreement]. Accessed November 8, 2021. https://pulse.kmu. gov.ua/ua. 
Romanova, Tatiana. "The Concept of 'Resilience' in EU External Relations: A Critical Assessment." European Foreign Affairs Review 24, no. 3 (2019): 349-366.

Rouet, Gilles and Gabriela Carmen Pascariu, eds. Resilience and the EU's Eastern Neighbourhood Countries. (London, UK: Palgrave, Springer, 2019).

Schumacher, Tobias, Andreas Marchetti and Thomas Demmelhuber, eds. The Routledge Handbook on the European Neighbourhood Policy." (London, UK: Routledge Press, 2017).

Soloninka, Deanna. “The EU Support Group for Ukraine: Quiet Politics of Substantive Reform?" European Futures, July 22, 2020. Accessed September 1, 2021. https:// www.europeanfutures.ed.ac.uk/the-eu-support-group-for-ukraine-quiet-politicsof-substantive-reform/.

Tocci, Nathalie "Resilience and the Role of the European Union in the World." Contemporary Security Policy 41, no. 2 (July 2020): 176-194, https://doi.org/10.108 o/1352326o.2019.1640342.

Urban, Mark. "The Yulia Tymoshenko Contradiction." BBC News. December 10, 2013. Accessed November 8, 2021. https://www.bbc.com/news/world-europe-25305254.

Van der Loo, Guillaume and Peter van Elsuwege. "Competing Paths of Regional Economic Integration in the Post-Soviet Space: Legal and Political Dilemmas for Ukraine." Review of Central and East European Law 37 (4) (2012): 421-447.

Van der Loo, Guillaume and Tinatin Akhvlediani. "Catch Me if You Can: Updating the Eastern Partnership Association Agreements and DCFTAs." CEPS. May 18, 2020. Accessed November 8, 2021. https:/www.ceps.eu/wp-content/uploads/2020/05/ GVDL-and-TA-Updating-AA-DCFTAs.pdf $>$.

Van Elsuwege, Peter and Roman Petrov, eds. Legal Approximation of EU Law in the Eastern Neighbourhood of the EU:Towards a Common Regulatory Space? (London, UK: Routledge Press, 2014).

Van Elsuwege, Peter and Roman Petrov, eds. Post-Soviet Constitutions and Challenges of Regional Integration: Adapting to European and Eurasian integration projects (London, UK: Routledge Press, 2017).

Prof. Dr. Roman Petrov is Head of Jean Monnet Centre of Excellence in EU Studies and Jean Monnet Chair in EU Law at the National University of Kyiv-Mohyla Academy. He is the founder and first elected president of the Ukrainian European Studies Association. Areas of Prof. Dr. Petrov's research and teaching include: EU Law, EU Business Law; EU External Relations Law; Approximation and Harmonisation of Legislation in the EU; Legal Aspects of Regional Integration in the Post-Soviet Area.

Dr. Oksana Holovko-Havrysheva is the associate professor of the International and European Law Department at the National University of Kyiv-Mohyla Academy. She holds the position of the associate professor of the European Law Department of the Ivan Franko National University of Lviv and chairs the Jean Monnet Centre of Excellence 
of the Implementation of the EU-Ukraine Association Agreement

"Western Ukrainian Research Center for European Studies." Currently she occupies the acting President of the Ukrainian European Studies Association. Her research and teaching areas cover the EU Law, EU Economic Law, EU Consumer Protection Law, Public Policy-Making in the EU and the legal regulation of the cooperation between the EU and the Eastern European States.

Acknowledgements: This work was carried out thanks to the financial support for the research by the Jean Monnet Network "Revitalising the Study of EU Single Market Integration in a Turbulent Age (VISTA)," Grant decision no 2019-16o9/oo1-0o1 and Jean Monnet Module "EU Studies Research Laboratory," Grant decision no 2020619982/001-0o1. 


\title{
Стійкість у Контексті Імплементації Угоди про Асоціацію між Україною та Європейським Союзом
}

\author{
Роман Петров \\ Професор \\ Національний університет “Києво-Могилянська академія”, Україна \\ Оксана Головко-Гавришева \\ Доцентка \\ Національний університет “Києво-Могилянська академія” / Львівський \\ національний університет імені Івана Франка, Україна
}

\begin{abstract}
Анотація
У цій статті досліджено вплив практик забезпечення стійкості у процесі імплементації Угоди про Асоціацію між Україною та ЄС (УАЄС). Також у ній проаналізовано основні законодавчі та інституційні інструменти, які спрямовані на посилення стійкості при інтеграції ринку України із ЄС. Два приклади представлено у цьому дослідженні: у першому випадку йдеться про переговори між Україною та ЄС про укладення Угоди про оцінку та прийнятність промислової продукції (ACAA); у другому - про спір між Україною та ЄC щодо заборони експорту лісу-кругляка. У обох випадках інституції ЄС та Україна засвідчують високий рівень гнучкості задля досягнення високого ступеня взаємодії з Спільним ринком ЄС. У випадку України інституційний механізм Угоди про Асоціацію часто не використовується як форум для ефективного обговорення і пошуку рішень для нагальних проблем порядку денного двосторонньої співпраці. Відтак, надалі існує потреба в узгодженій, прозорій та ефективній структурі інституційної співпраці між Україною та ЄС.
\end{abstract}

Ключові слова: стійкість, АСАА, пандемія, ЄС, Україна, Спільний ринок ЄС, Угода про Асоціацію між Україною та ЄС 